\title{
The Immunogenetics of Psoriasis and Implications for Drug Repositioning
}

\author{
Xuan Xu (iD) and Hong-Yu Zhang * \\ Hubei Key Laboratory of Agricultural Bioinformatics, College of Informatics, Huazhong Agricultural University, \\ Wuhan 430070, China; xxpinky@webmail.hzau.edu.cn \\ * Correspondence: zhy630@mail.hzau.edu.cn
}

Received: 31 October 2017; Accepted: 4 December 2017; Published: 8 December 2017

\begin{abstract}
Psoriasis is a genetically-regulated, T lymphocyte-mediated autoimmune skin disease that causes systemic damage, seriously affecting patient quality of life and survival. Psoriasis treatments, which aim to control the disease's development, are greatly limited because its etiology and pathogenesis have not yet been fully elucidated. A large number of studies have demonstrated that immunogenetic elements are the most important factors responsible for psoriasis susceptibility. This paper delineates the immunogenetic mechanisms of psoriasis and provides useful information with regards to performing drug repositioning for the treatment of psoriasis.
\end{abstract}

Keywords: psoriasis; immunogenetics; genetics; susceptible genes; drug repositioning

\section{Introduction}

Psoriasis is a clinically common chronic inflammatory disease. Psoriasis patients experience skin tissue damage and can also simultaneously develop other systemic complications. This disease usually manifests with clinical and histological features, such as oval-shaped plaques with adherent, uplifted silver scales, dividing lines, and erythema. Scales are formed due to the incomplete keratinization of keratinocytes, which consists of prematurely overproliferated epidermal and cuticle-retained nuclei (parakeratosis). Compared to normal skin, an increased rate of mitosis in basal keratinocytes is observed. Since psoriasis is a skin-specific T-cell-mediated autoimmune disease, epidermal growth factors, nerve growth factors, adhesion factors, chemokines, neuropeptides, and T-cell receptors are involved in its pathogenesis. This disease affects approximately $1-3 \%$ of the world's population [1] Even after continuous developments and progress, the incidence of skin diseases continues to increase [2].

Epidemiological studies have established a genetic basis for psoriasis, with an estimated heritability of $60-90 \%$, which is the highest among complex genetic diseases [3]. Familial studies have indicated higher incidences among primary and secondary relatives of psoriasis patients than among the general population, and three times the likelihood of incidence among identical twins than that of fraternal twins [4]. Approximately $70 \%$ of children with psoriasis present with family history of the disease [5]. Even though the genetic mechanisms of psoriasis are complex, a plausible explanation for its pathogenesis can be attributed to the abnormal activation of $\mathrm{T}$ cells and their migration into the skin, leading to the accumulation of inflammatory cells. CD4+ and CD8+ T cells then co-regulate the development of psoriatic lesions [5,6]. This hypothesis further confirms the importance of immunization in counteracting the pathogenicity of psoriasis.

Although the exact cause of psoriasis remains unknown, immune factors play a very important role in its pathogenesis. The use of immunotherapy has received increased attention due to the rapid progress in understanding the immune system-related psoriatic mechanisms. In fact, the psoriasis drug market is currently dominated by various types of antibody-based drugs [7]. Since psoriasis 
is a chronically recurrent disease, many patients require long-term treatment. However, up to $30 \%$ of the patients treated with anti-tumor necrosis factor (TNF) drugs (such as adalimumab) respond inadequately, and up to $50 \%$ lose response over time [8]. Even though anti-IL-17A drugs show better safety profiles compared to anti-TNF agents, they are often associated with an increased risk of severe infection and allergic, immunological, or other unwanted reactions [9]. Therefore, the biggest concern regarding these immunotherapies is with respect to their safety. The continued development of effective therapies for psoriasis is urgently needed. Drug repositioning (the application of approved drugs for new therapies) has provided an efficient route for drug discovery. It has the potential to greatly benefit affected patients by analyzing the immunogenetic mechanism of psoriasis. In this paper, following the analysis of the immunogenetic mechanism of psoriasis, we show the great potential of genetics-directed drug repositioning [10] in psoriasis treatment.

\section{The Immunogenetics of Psoriasis}

Like many immune-mediated diseases, psoriasis is associated with the major histocompatibility complex (MHC) alleles [11]. The ability of a series of immunosuppressive agents, such as cyclosporine, denileukin diftitox, and alefacept, to improve psoriasis has revealed the importance of the immune system in its pathogenesis. Psoriasis was once thought to be a disease associated with the TNF-mediated Th1-type immune response. Recently, the cellular and molecular contributions to the overactive immune response were further elucidated. The expression profiles of genes encoding Th1, Th2, and Th17 cytokines were extensively evaluated in differentiated skin cells of psoriatic patients. Th1 and Th22 cells were found to produce abundant psoriatic cytokines, such as IL-17, IFN- $\gamma$, $T N F$, and IL-22, which mediated the potentiation of keratinocytes on psoriatic inflammation. Although the role of Th1 cells in psoriasis is questioned, the use of cytokine antibodies in treatments has shown that $I L-23, T N F$, and $I L-17$ play key roles in the pathogenesis of psoriasis [12,13].

More than 40 regions in the human genome have been associated with psoriasis [14], such as HLA-Cw6, IL12B, IL23R, LCE3A, LCE3D, and STAT3C. The chromosomal region that is thought to encode a psoriasis gene is referred to as the psoriasis susceptibility (PSORS) locus and is currently known to encode at least 15 different PSORS loci, which are mainly linked by a chain analysis of multiple members of the psoriasis family. The first gene found to be significantly susceptible to psoriasis was HLA-Cw6, which is located at PSORS1 with the chromosome position 6p21.3. Pathological studies have shown that HLA-C plays an important role in the antigen presentation of CD8+ T cells, and the CD8+ T cells in turn play a dominant role in the development and progression of psoriatic lesions. Therefore, HLA-C may be responsible for the expression profiles of genes important to psoriasis [15]. Studies have also shown that both the ZNF816A and GJB2 loci are significantly associated with psoriasis in the German population, while ERAP1 and ZNF816A are associated with type 1 (early-onset) psoriasis in the Chinese Han population. The disease susceptibility between the Chinese and European populations is heterogeneous, and may vary due to geographical differences, such as environmental factors affecting the disease susceptibility loci [16]. In general, after the classification of the associated genes, different types of biological mechanisms have been implicated in contributing to the etiology of psoriasis, including innate and adaptive immunity.

\subsection{Genes Associated with Innate Immunity}

The innate immune system provides an early response mechanism to host damage by identifying pre-formed non-specific effectors. There is evidence of psoriasis-associated inherent immune system disorders. For example, clinical observations indicate the importance of the congenital cytokine, interferon-alpha, as a psoriasis inducer [17].

$\mathrm{NF}-\mathrm{kB}$ is a key regulatory element involved in a variety of intrinsic immunoregulatory and inflammatory pathways, cellular proliferation and differentiation, and apoptosis. Studies have confirmed that the NF- $\mathrm{KB}$ pathway is activated in psoriatic lesions and is downregulated after successful treatment [18]. We analyzed the genome-wide association study (GWAS) data and found 
that TYK2, caspase recruitment domain family member 14 (CARD14) [15], NFK-BIA [19], TNFAIP3 [19], TNIP1 [19], IL-36RN [20], and other genetic polymorphisms in this pathway are associated with the pathogenesis of psoriasis. CARD14 expressed and regulated NF- $\mathrm{KB}$ in keratinocytes and was recently found to be a pathogenic gene of PSORS2 [21]. Moreover, all NF- $\mathrm{KB}$ proteins contain the Rel homologous domains that mediate DNA binding and dimerization.

Generalized pustular psoriasis (GPP) is often found in patients that exhibit or previously exhibited psoriasis vulgaris (PV). Interestingly, the interleukin-36 receptor antagonist gene (IL-36RN) is mainly expressed in the skin. It is largely responsible for encoding a soluble molecule, IL-36 receptor antagonist $(I L-36 R \alpha)$, which neutralizes the activation of NF-KB downstream signaling via the IL-36 receptors [20]. Animal experiments and population studies have found that most individual GPP cases were caused by homozygous or complex heterozygous mutations of IL-36RN [22,23].

RNF114 regulates innate immune system-related signaling molecules, such as IL-1, IL-6, and IL-29, which eventually results in the EXOC2-mediated production of IF-1. The IF-1 gene encodes a viral RNA-activated apoptotic protein that initiates cellular antiviral and apoptotic responses upon sensing viral nucleic acids in the cytoplasm and protects the body by sensing and triggering the removal of virus-infected cells. The gene has been confirmed to be associated with psoriasis in both the Chinese and European populations [24].

Skin barrier function plays a dominant position in non-specific immunity, as the skin and mucous membranes constitute the body's first immune barrier. Recently, researchers have focused on identifying new genetic markers associated with psoriatic skin barrier function. The terminal step of the keratinization process was associated with the formation of a highly specialized insoluble protein-lipid structure called the keratinized envelope (CE). The corneal capsule was essential for the normal functioning of the epidermal barrier. Thus, any abnormality in the expression of genes encoding portions of the envelope's structure or of proteins involved in the enzymatic process may cause interference at different stages of keratinocyte differentiation, ultimately leading to the dysfunction of the epidermal barrier [25].

The epidermal differentiation complex (EDC) in the PSORS4 locus located on chromosome 1q21 contains genes that are expressed at various stages of the keratinization process. Currently, more than 45 genes have been identified in this complex. The EDC contains genes for epidermal regeneration (such as the S100 gene family) and terminally differentiated keratinocytes (small proline-enriched protein and advanced envelope protein (LCE protein)). These genes have different expression profiles in psoriasis. The LCE gene cluster is located in the PSORS4 locus of chromosome 1q21.3 and is a part of the EDC complex. More recently, the gene family encoding the late keratinized envelope (LCE) proteins has gathered increasing interest from researchers. The family can be divided into six subfamilies named LCE1-LCE6. Domestic and international scholars have confirmed that mutations or deletions in the LCE gene cluster ( $L C E 3 B$ and $L C E 3 C$ gene single-nucleotide polymorphism (SNP) point) can cause skin barrier damage, leading to psoriasis [26].

\subsection{Genes Associated with Adaptive Immunity}

Adaptive immunity appears to be crucial for psoriatic pathogenesis, as the human leukocyte antigen (HLA) region is the most important susceptible site for psoriasis. Approximately $40 \%$ of the genes in the HLA region encode immune defense-related proteins [27]. A single-nucleotide polymorphism (SNP) possessing strong linkage disequilibrium (LD) along with the HLA-Cw6 allele produces the strongest correlation signal in all GWAS. Moreover, the HLA-Cw6 allele is also closely related to early-onset psoriasis in various races, which is supported by the fact that the antigenicity of the immune system is vital to the pathogenesis of psoriasis. Interestingly, a recent study has revealed a new pathway for the pathogenesis of psoriasis i.e., a melanocyte-specific response pathway where HLA-C ${ }^{*} 06: 02$ produces an autoimmune response against melanocytes by antigen presentation [28,29]. Additionally, the ERAP1 gene is mainly involved in the processing of HLA class I molecules. Mutation of ERAP1 affects the susceptibility of individuals carrying the HLA-C allele carriers, and studies have 
confirmed that the HLA-Cw6 allele is associated with this effect. A GWAS study showed a significant interaction between the HLA-Cw6 allele and rs27524-labeled ERAP1 [30].

The role of $I L-23 /$ Th17 in psoriatic pathogenesis has become apparent in recent years with the discovery of the Th17 T cell subtype and the key Th17-polarized cytokine, IL-23. Many genes (e.g., IL-12B, IL-23A, IL-23R, TRAF3IP2, and TYK2) are significantly associated with psoriasis. Th17 cells are a type of novel effector $T$ cell that secretes cytokines such as $I L-21$ and $I L-17$. IL-23 is a proinflammatory cytokine expressed in T cells, B cells, monocytes, mast cells, and endothelial cells. Both $I L-12 B$ and IL-23R have been validated in the Chinese population. A study found that TNF (SNP rs3093662) is a susceptible gene for psoriasis in the Chinese population [19]. Moreover, $I L-12$ and $I L-23$ contain a common p40 chain, and the IL-12p40 subunit binds to a unique subunit, p19, to form IL-23 (p19/p40 dimer). The expression levels of the p19 and p40 genes in psoriatic lesions are increased, indicating that $I L-23$ may play a major role in psoriatic lesions. Additionally, a GWAS study found that psoriasis was associated with mutations in STAT3 (signal transduction and transcriptional activator 3), which is a key molecule in signaling cascades via several cytokines, including $I L-6, I L-10, I L-22$, and $I L-23$. Since STAT3 is necessary for signal transduction via IL-23R, it is essential for Th17 polarization. Furthermore, psoriasis-related mutations in STAT3 may reduce the threshold for the IL-23 signal required to induce Th17 polarization. Targeted biologics have a high efficacy in psoriasis, and the high expression of $I L-23 A$ and IL-12B in psoriatic lesions also supports the above hypothesis regarding the pathogenesis of psoriasis [31,32].

Interestingly, associations of regions encoding Th2-related genes, particularly IL-4, IL-5, and IL-13, with the region of chromosome 5 q31 containing multiple cytokine genes have also been found in patients with psoriasis [33]. IL-4 and IL-13 not only promote T cells toward Th2 differentiation, but also inhibit the development of mature Th17 cells. IL-4 promotes both Th1 cell proliferation and IL-23 expression, leading to a reduction in the number of Th17 cells. Although a number of studies have suggested that Th2 is not associated with psoriasis development, the strong correlation found between psoriasis and the GWAS between the genes encoding the cytokines $I L-4$ and $I L-13$ suggests a role for the Th2 pathway in psoriasis pathogenesis [33]. Erythrodermic psoriasis (EP) is among the most serious forms of psoriasis that affects human beings. The balance between Th1 and Th2 cells plays an important role in the pathogenesis of EP. Th1 cells induce the disease, while Th2 cells accelerate the inflammatory process, triggering the risk of infection. Th17/Treg may also lead to EP by binding to Th1 and Th2 cells (results summarized in Table 1) [34].

Table 1. Genes associated with the immunogenetics of psoriasis.

\begin{tabular}{cllc}
\hline Gene & \multicolumn{1}{c}{ Biologic Pathway } & \multicolumn{1}{c}{ Protein Classification ${ }^{\text {a }}$} & Reference \\
\hline B3GNT2 & Adaptive immunity & Beta-1,3-N-acetylglucosaminyltransferase family & {$[15,19]$} \\
\hline CARD14 & Innate immunity; NF-kB signaling & Caspase recruitment domain-containing protein & {$[15,19,21,35]$} \\
\hline CARM1 & Innate immunity; NF-kB signaling & Protein arginine methyltransferase (PRMT) family & {$[19,21]$} \\
\hline DDX58 & $\begin{array}{l}\text { Innate immunity; interferon } \\
\text { gamma signaling }\end{array}$ & DEAD box proteins & {$[15,19]$} \\
\hline EGFR & $\begin{array}{l}\text { Adaptive immunity; } \\
\text { organism-specific biosystem }\end{array}$ & Transmembrane glycoprotein & {$[36]$} \\
\hline ELMO1 & Innate immunity; signaling by PTK6 & $\begin{array}{l}\text { Member of the engulfment and cell motility } \\
\text { protein family }\end{array}$ & {$[19]$} \\
\hline ERAP1 & $\begin{array}{l}\text { Adaptive immunity; } \\
\text { antigen presentation }\end{array}$ & $\begin{array}{l}\text { Aminopeptidase involved in trimming HLA class } \\
\text { I-binding precursors }\end{array}$ & {$[30]$} \\
\hline ETS1 & $\begin{array}{l}\text { Adaptive immunity; immune } \\
\text { response IL-23 signaling pathway }\end{array}$ & ETS family of transcription factors & {$[19]$} \\
\hline EXOC2 & $\begin{array}{l}\text { Innate immunity; innate } \\
\text { antiviral signaling }\end{array}$ & Component of the exocyst complex & {$[15,19,24]$} \\
\hline FBXL19 & Innate immunity; NF-KB signaling & $\begin{array}{l}\text { Member of the Skp1-Cullin-F-box family of E3 } \\
\text { ubiquitin ligases }\end{array}$ & {$[37]$} \\
\hline HLA-C & $\begin{array}{l}\text { Adaptive immunity; } \\
\text { antigen presentation }\end{array}$ & HLA class I heavy chain paralogues & {$[15,19,30]$} \\
\hline
\end{tabular}


Table 1. Cont.

\begin{tabular}{|c|c|c|c|}
\hline Gene & Biologic Pathway & Protein Classification $^{a}$ & Reference \\
\hline IFIH1 & $\begin{array}{l}\text { Innate immunity; innate antiviral } \\
\text { signaling }\end{array}$ & DEAD box protein & [30] \\
\hline IL-12B & Adaptive immunity; IL-23/Th17 axis & Subunit of interleukin 12 & [30] \\
\hline IL-13 & $\begin{array}{l}\text { Adaptive immunity; B-cell maturation } \\
\text { and differentiation }\end{array}$ & immunoregulatory cytokine & {$[30,33]$} \\
\hline IL-17A & $\begin{array}{l}\text { Adaptive immunity; immune } \\
\text { response IL-23 signaling pathway }\end{array}$ & $\begin{array}{l}\text { Proinflammatory cytokine produced by activated } \\
\mathrm{T} \text { cells }\end{array}$ & [38] \\
\hline IL23A & Adaptive immunity; IL-23/Th17 axis & $\begin{array}{l}\text { Subunit of the heterodimeric cytokine interleukin } \\
23 \text { (IL23) }\end{array}$ & {$[15,30]$} \\
\hline IL-23R & Adaptive immunity; IL-23/Th17 axis & Subunit of the receptor for IL23A/IL23 & [30] \\
\hline IL-28RA & Innate immunity; IFN signaling & Class II cytokine receptor family & [30] \\
\hline IL-4 & Adaptive immunity; Th2 signaling & Pleiotropic cytokine produced by activated T cells & {$[33,39]$} \\
\hline IL-5 & Adaptive immunity; Th2 signaling & $\begin{array}{l}\text { Cytokine that acts as a growth and differentiation } \\
\text { factor for both B cells and eosinophils }\end{array}$ & [33] \\
\hline IL-36RN & Innate immunity; NF- $\kappa B$ signaling & Member of the interleukin 1 cytokine family & {$[22,23]$} \\
\hline KLF4 & Innate immunity & Kruppel family of transcription factors & [19] \\
\hline LCE3B/LCE3C & $\begin{array}{l}\text { Innate immunity; skin barrier } \\
\text { function }\end{array}$ & Late Cornified Envelope (LCE) & {$[26,30]$} \\
\hline MBD2 & Adaptive immunity & $\begin{array}{l}\text { Transcriptional repressor that binds to methylated } \\
\text { DNA }\end{array}$ & [19] \\
\hline NFKBIA & Innate immunity; NF- $\kappa B$ signaling & Member of the NF- $\mathrm{kB}$ inhibitor family & {$[19,30]$} \\
\hline NOS2 & Innate immunity & Reactive free radical & {$[15,19]$} \\
\hline NOS3 & $\begin{array}{l}\text { Innate immunity; immune response } \\
\text { Fc epsilon RI pathway }\end{array}$ & Reactive free radical & [40] \\
\hline REL & Innate immunity; NF- $\kappa \mathrm{B}$ signaling & $\begin{array}{l}\text { Rel homology domain/immunoglobulin-like fold, } \\
\text { plexin, transcription factor (RHD/IPT) family }\end{array}$ & [30] \\
\hline RNF114 & $\begin{array}{l}\text { Innate immunity; innate antiviral } \\
\text { signaling }\end{array}$ & Ring finger protein 114 & [19] \\
\hline RUNX3 & Adaptive immunity; T-cell activation & $\begin{array}{l}\text { Runt domain-containing family of transcription } \\
\text { factors }\end{array}$ & [19] \\
\hline SOCS1 & $\begin{array}{l}\text { Adaptive immunity; immune } \\
\text { response IFN alpha/beta signaling } \\
\text { pathway }\end{array}$ & Member of the STAT-induced STAT inhibitor (SSI) & [19] \\
\hline STAT3 & Adaptive immunity & STAT family of transcriptional activators & {$[15,19]$} \\
\hline STAT5A & Adaptive immunity & STAT family of transcriptional activators & {$[15,19]$} \\
\hline STAT5B & Adaptive immunity & STAT family of transcriptional activators & {$[15,19]$} \\
\hline TAGAP & Adaptive immunity & $\begin{array}{l}\text { Member of the Rho GTPase-activator protein } \\
\text { superfamily }\end{array}$ & [19] \\
\hline TNFAIP3 & Innate immunity; NF- $\mathrm{kB}$ signaling & Zinc finger protein and ubiqitin-editing enzyme & [19] \\
\hline TNFRSF9 & Adaptive immunity & TNF-receptor superfamily & [19] \\
\hline TNIP1 & Innate immunity; NF- $\mathrm{\kappa B}$ signaling & TNFAIP3 Interacting Protein 1 & [30] \\
\hline TRAF3IP2 & Innate immunity; NF- $\mathrm{\kappa B}$ signaling & $\begin{array}{l}\text { Regulate responses to cytokines by members of the } \\
\text { Rel/NF- } \mathrm{B} \text { transcription factor family }\end{array}$ & [30] \\
\hline TYK2 & Innate immunity; IFN signaling & Janus kinases (JAKs) protein families & [30] \\
\hline UBE2L3 & Innate immunity; NF- $\mathrm{kB}$ signaling & E2 ubiquitin-conjugating enzyme family & [19] \\
\hline VDR & $\begin{array}{l}\text { Innate Immunity; Vitamin D } \\
\text { Metabolism, organism-specific } \\
\text { biosystem }\end{array}$ & Nuclear hormone receptor for vitamin D3 & [40] \\
\hline VEGF & $\begin{array}{l}\text { Innate immunity; immune response } \\
\text { Fc epsilon RI pathway }\end{array}$ & Member of the PDGF/VEGF growth factor family & [41] \\
\hline $\mathrm{ZCH} 12 \mathrm{C}$ & Innate immunity & Zinc finger protein that regulates & [19] \\
\hline
\end{tabular}




\section{Implications for Drug Repositioning}

Psoriasis treatments mainly aim to eliminate skin damage and prevent recurrence. Patients suffering from mild psoriasis are treated with local drugs and targeted light therapy. Patients with more severe forms of psoriasis undergo systemic treatments, such as a combination of methotrexate and phototherapy. However, its long-term use is hampered by safety issues. Understanding the progress of psoriatic immunogenetics is crucial in developing biotherapies that target the immune system, ideally for patients with intensive forms of the disease. The common biotherapies for the treatment of psoriasis include monoclonal antibody against interleukin $I L-12$ and IL-23 (ustekinumab) and anti-cytokine therapies (e.g., anti-tumor necrosis factor (TNF) therapies (adalimumab, etanercept, and infliximab)) [42].

Despite the progress in drug development, the approved drugs used to treat psoriasis have many limitations and defects. In spite of the strong anti-inflammatory effects of hormonal drugs (e.g., hydrocortisone acetate, prednisolone, betamethasone, and dexamethasone), external hormones are a temporary solution as long-term use may degrade the patients' own hormone secretion glands, and lead to the re-emergence or a serious recurrence of the disease. Anti-tumor necrosis factor (TNF) drugs are first-line therapies for patients who exhibit immune tolerance under conventional systemic therapy. Although these treatments are relatively effective, about $30-50 \%$ of the patients respond inadequately $[8,43]$. Therefore, the development of new drugs to treat psoriasis has important research significance. A study has indicated that the medical genetics of drug targets may provide useful information with respect to drug repositioning, which involves predicting new activities and side effects of approved drugs [10]. This approach can accelerate the drug development process and reduce the associated risks. This paper mainly used the target-based approach to relocate a selection of approved drugs.

Analyzing the immune mechanisms and susceptibility genes of psoriasis not only deepens our understanding of the pathology, but also facilitates the use these susceptible genes as drug targets. The gain of function (GOF) and loss of function (LOF) mutations of pathogenic genes are the two major mechanisms that lead to the development of diseases. Therefore, drugs with appropriate modes of action (MoA) should be selected to treat the diseases i.e., inhibitors/antagonists should be used to combat GOF-induced diseases, whereas activators/agonists should be used to treat LOF-induced diseases [44].

We collected information on approved drugs that are used to treat psoriasis from the DrugBank (http:/ /www.drugbank.ca), TTD (http:/ /bidd.nus.edu.sg/BIDD-Databases/TTD/TTD.asp), and Clinical Trials (https://www.clinicaltrials.gov) websites. Furthermore, information regarding the GOF/LOF of pathogenic genes and the interactions between drugs and targets was collected from the OUGene website (http:/ / www.csbio.sjtu.edu.cn). Using this method to reverse analyze, we found that many of these drugs met the requirements of the aforementioned pharmacological mechanisms (Table 2), thereby demonstrating the reliability of this strategy for fast and effective drug discovery.

Additionally, we also selected a number of important genes from the list of pathogenic genes mentioned above as drug repositioning targets by querying the literature.

Studies have shown that STAT3 is the most common and easily activated STAT family member in human malignancies. STAT3-related skin diseases are characterized by epidermal hyperplasia and abnormal differentiation. STAT3 performs its biological function by regulating several genes associated with apoptosis and proliferation and has been the focus of recent clinical research [45]. It is present in the cytoplasm of untreated cells and can be affected by the cytokines $I L-6$ and $I L-10$, epidermal growth factor $(E G F)$, hepatocyte growth factor $(H G F)$, human epidermal growth factor receptor 2 (HER2/Neu), vascular endothelial growth factor $(V E G F)$, and other ligands along with human erythropoietin (EPO) and human granulocyte-macrophage colony stimulating factor (GM-CSF), among other factors. 
Table 2. Anti-psoriasis drugs and their medical genetics of targets.

\begin{tabular}{|c|c|c|c|}
\hline Target & Genetic Disease Pathogenesis ${ }^{a}$ & Drug (Mode of Action) ${ }^{b}$ & Current Drug Indication ${ }^{c}$ \\
\hline IL17-A & GOF & Secukinumab (inhibitor) & $\begin{array}{l}\text { Ankylosing Spondylitis (AS); Psoriatic Arthritis; Severe Plaque psoriasis; } \\
\text { Moderate Plaque psoriasis }\end{array}$ \\
\hline IL17-A & GOF & Ixekizumab (inhibitor) & Severe Plaque psoriasis; Moderate Plaque psoriasis \\
\hline NOS3 & GOF & Prednisone (inhibitor) & $\begin{array}{l}\text { Allergic Rhinitis (AR); Conjunctivitis, Seasonal Allergic; Psoriasis; } \\
\text { Prostate Cancer; Lymphoma; Hodgkins Disease; Tuberculosis }\end{array}$ \\
\hline NOS3/ARID5B & GOF & Methotrexate (inhibitor) & $\begin{array}{l}\text { Severe Psoriasis; Systemic Lupus Erythematosus (SLE); Cancer, Breast; } \\
\text { Acute Lymphocytic Leukemia (ALL) }\end{array}$ \\
\hline STAT3 & GOF & Acitretin (inhibitor) & Keratinization disorders; Severe Psoriasis \\
\hline TNF & GOF & Infliximab (inhibitor) & $\begin{array}{l}\text { Ankylosing Spondylitis (AS); Crohn's Disease (CD); Plaque Psoriasis; } \\
\text { Psoriatic Arthritis; Rheumatoid Arthritis (RA); Ulcerative Colitis (UC) }\end{array}$ \\
\hline TNF & GOF & Golimumab (inhibitor) & $\begin{array}{l}\text { Ankylosing Spondylitis (AS); Rheumatoid Arthritis; Psoriatic Arthritis; } \\
\text { Ulcerative Colitis }\end{array}$ \\
\hline TNF/NOS3 & GOF & Apremilast (inhibitor) & $\begin{array}{l}\text { Psoriatic arthritis aggravated; Severe Plaque psoriasis; Moderate } \\
\text { Plaque psoriasis }\end{array}$ \\
\hline TNF/TNFRSF1B & GOF & Etanercept (inhibitor) & $\begin{array}{l}\text { Ankylosing Spondylitis (AS); Graft Versus Host Disease (GVHD); } \\
\text { Hidradenitis Suppurativa (HS); Plaque Psoriasis; Psoriatic Arthritis; } \\
\text { Rheumatoid Arthritis }\end{array}$ \\
\hline VDR & GOF & Atocalcitol (inhibitor) & Psoriasis \\
\hline VDR & GOF & Tisocalcitate (inhibitor) & Psoriasis \\
\hline VDR & GOF & Tacalcitol (inhibitor) & Psoriasis \\
\hline
\end{tabular}

a,b Derived from OUgene (http:/ / www.csbio.sjtu.edu.cn); ${ }^{c}$ Derived from TTD, DrugBank, and ClinicalTrials. GOF: gain of function. 
Psoriasis patients mainly express VEGF in the cytoplasms of keratinocytes from the basal layer to the granular layer. Contrastingly, VEGF has little or no expression in normal epidermis. In psoriasis patients, the STAT3 protein is located in the cytoplasm and nuclei of the whole or middle layer of the epidermis, whereas STAT3 is only present in the cytoplasm of the epidermal basal layer in normal epidermis. Therefore, VEGF and STAT3 protein expression levels are higher in the skin lesions of psoriasis patients than in normal skin. Studies have shown that both proteins exhibit synergistic effects in psoriasis pathogenesis [46]. EGFR is a member of the epidermal growth factor family and is a transmembrane glycoprotein present on the surfaces of keratinocytes. It exhibits tyrosine kinase activity and plays important roles in the activation phases of proliferative signaling pathways. Its main ligands are epidermal growth factor $(E G F)$ and TGF- $\alpha$, among others; TGF- $\alpha$ can be formed by keratinocytes and then act in an autocrine manner, and EGFR can combine into dimers. Stimulation of the intrinsic tyrosine kinase function activates EGFR, which triggers downstream signal transduction pathways, such as RAS/ mitogen-activated protein kinases (MAPK), P13/AKT, and Janus kinase (JAK)/STAT, and it is found in many tumors. Drugs for STAT3 are under investigation and have achieved satisfying therapeutic efficacy. One example is Benzo[b]thiophen-2-yl-3-bromo-5-hydroxy-5H-furan-2-one (BTH), a simple and interesting synthetic derivative of a natural compound separated from sponges, which can reduce the proliferation of keratinocytes by inhibiting the anti-inflammatory activity of the NF- $\mathrm{kB}$ signaling pathway and impair STAT3 phosphorylation, preventing it from translocating to the nucleus and resulting in a decrease in keratinocyte proliferation [45].

As mentioned earlier, recent studies have also found interleukin $1 \beta(I L-1 \beta)$, tumor necrosis factor (TNF) [47], vitamin D receptor (VDR) [48], nitric oxide synthase 3 (NOS3) [49], and other genes to be overexpressed in psoriasis patients (GOF). Therefore, we used inhibitors for these targets and in turn designed drug repositioning strategies for psoriasis.

By performing psoriasis-related patent and literature searches, we found 12 of these drugs to be previously reported, further demonstrating our target-based drug repositioning method to have a high degree of accuracy and also indicating that the drugs we predicted by this method to be promising for psoriasis treatment (results summarized in Table 3).

Table 3. Potential anti-psoriasis drugs predicted by medical genetics of targets and related literature/patents.

\begin{tabular}{|c|c|c|c|c|}
\hline Target & Genetic Disease Pathogenesis ${ }^{a}$ & Drug (Mode of Action) ${ }^{b}$ & Current Drug Indication ${ }^{c}$ & Reference \\
\hline EGFR & GOF & Zalutumumab (inhibitor) & Head and neck cancer & [50] \\
\hline EGFR & GOF & Panitumumab (inhibitor) & Colorectal cancer & {$[51,52]$} \\
\hline IL17-A & GOF & Vidofludimus (inhibitor) & Multiple sclerosis & n.a. d \\
\hline IL17-A & GOF & Cetuximab (inhibitor) & Colorectal cancer; cancer & {$[55,56]$} \\
\hline IL1-B & GOF & Glucosamine (inhibitor) & Osteoarthritis & [58] \\
\hline IL6 & GOF & Ibudilast (inhibitor) & Allergic conjunctivitis & n.a. \\
\hline STAT3 & GOF & Atiprimod (inhibitor) & Inflammatory bowel disease & n.a. \\
\hline TNF & GOF & Certolizumab (inhibitor) & Rheumatold arthritis & {$[60-62]$} \\
\hline TNF & GOF & Lenalidomide (inhibitor) & Anaemia & {$[63,64]$} \\
\hline VEGF & GOF & Bevacizumab (inhibitor) & Glaucoma & {$[65,66]$} \\
\hline VEGF & GOF & Minocycline (inhibitor) & Bacterial infection & {$[67,68]$} \\
\hline VEGF & GOF & Vandetanib (inhibitor) & Solid tumours & [69] \\
\hline
\end{tabular}




\section{Conclusions and Perspective}

Psoriasis is an incurable disease that causes lifelong suffering in affected individuals. Currently, medical science faces challenges such as treatment failure, drug compliance, and drug side effects with respect to psoriasis treatments. In order to improve these deficiencies, we need a more effective treatment strategy. Rapid development in genomics and genetics has facilitated the identification of several psoriasis susceptibility genes and a comprehensive understanding of the immune mechanisms of psoriasis. Drug repositioning strategies based on immunogenetics can be used to effectively detect a drug's potential in treating psoriasis and can even provide guidance for precision medicine. This approach can greatly influence the limitations of traditional treatments.

Given the current progress in science and technology, the analysis of single-nucleotide polymorphisms (SNPs) and copy number variants (CNVs) provides us with powerful tools to identify high-risk groups and disease-related genes, design and test medicines, and perform basic research in biology, which deepens our understanding of disease pathology and individual genetic differences. Moreover, the ability to study biological phenomena at omics levels is expected to lead to significant advances in precision medicine, as patients can be treated according to their own molecular characteristics. More importantly, the efficacy and toxicity of drugs can be predicted via genetic pharmacology and pharmacogenomics research, thus truly realizing the idea of personalized treatment. Therefore, by identifying differentially expressed genes (GOF or LOF) in each affected patient and using individual genome differences to guide medication, a specifically targeted drug can be chosen to achieve better therapeutic effects.

Acknowledgments: We are grateful to Yun Hua Deng, Department of Dermatology, Tongji Hospital, Tongji Medical College, Huazhong University of Science and Technology, for helping us to modify the manuscript. This work supported by the Fundamental Research Funds for the Central Universities (Grants 2662015PY004 and 2662017PY115).

Author Contributions: Hong-Yu Zhang conceived and designed the experiments; Xuan Xu analyzed the data; and $\mathrm{Xuan} \mathrm{Xu}$ wrote the paper. Hong-Yu Zhang helped in preparing the manuscript and revised the manuscript.

Conflicts of Interest: The authors declare no conflict of interest.

\section{References}

1. Mease, P.J.; Armstrong, A.W. Managing patients with psoriatic disease: The diagnosis and pharmacologic treatment of psoriatic arthritis in patients with psoriasis. Drugs 2014, 74, 423-441. [CrossRef] [PubMed]

2. Michalek, I.M.; Loring, B.; John, S.M. A systematic review of worldwide epidemiology of psoriasis. J. Eur. Acad. Dermatol. Venereol. 2017, 31, 205-212. [CrossRef] [PubMed]

3. Elder, J.T.; Nair, R.P.; Guo, S.W.; Henseler, T.; Christophers, E.; Voorhees, J.J. The genetics of psoriasis. Arch. Dermatol. 1994, 130, 216-224. [CrossRef] [PubMed]

4. Di Lernia, V.; Ficarelli, E.; Lallas, A.; Ricci, C. Familial aggregation of moderate to severe plaque psoriasis. Clin. Exp. Dermatol. 2014, 39, 801-805. [CrossRef] [PubMed]

5. Morris, A.; Rogers, M.; Fischer, G.; Williams, K. Childhood psoriasis: A clinical review of 1262 cases. Pediatr. Dermatol. 2001, 18, 188-198. [CrossRef] [PubMed]

6. Gervin, K.; Vigeland, M.D.; Mattingsdal, M.; Hammerø, M.; Nygård, H.; Olsen, A.O.; Brandt, I.; Harris, J.R.; Undlien, D.E.; Lyle, R. DNA methylation and gene expression changes in monozygotic twins discordant for psoriasis: Identification of epigenetically dysregulated genes. PLoS Genet. 2012, 8, e1002454. [CrossRef] [PubMed]

7. Sala, M.; Elaissari, A.; Fessi, H. Advances in psoriasis physiopathology and treatments: Up to date of mechanistic insights and perspectives of novel therapies based on innovative skin drug delivery systems (ISDDS). J. Controll. Release 2016, 239, 182-202. [CrossRef] [PubMed]

8. Mota, F.; Neves, E.; Oliveira, J.C.; Selores, M.; Torres, T. Importance of immunogenicity testing for cost-effective management of psoriasis patients treated with adalimumab. Acta Dermatovenerol. Alp. Pannonica Adriat. 2017, 26, 33-35. [CrossRef] [PubMed]

9. Boyman, O.; Comte, D.; Spertini, F. Adverse reactions to biologic agents and their medical management. Nat. Rev. Rheumatol. 2014, 10, 612-627. [CrossRef] [PubMed] 
10. Wang, Z.Y.; Zhang, H.Y. Rational drug repositioning by medical genetics. Nat. Biotechnol. 2013, 31, 1080-1082. [CrossRef] [PubMed]

11. Bowcock, A.M. The genetics of psoriasis and autoimmunity. Annu. Rev. Genom. Hum. Genet. 2005, 6, 93-122. [CrossRef] [PubMed]

12. Harden, J.L.; Krueger, J.G.; Bowcock, A.M. The immunogenetics of psoriasis: A comprehensive review. J. Autoimmun. 2015, 64, 66-73. [CrossRef] [PubMed]

13. Lowes, M.A.; Suárez-Fariñas, M.; Krueger, J.G. Immunology of psoriasis. Annu. Rev. Immunol. 2014, 32, 227-255. [CrossRef] [PubMed]

14. Mahil, S.K.; Capon, F.; Barker, J.N. Genetics of psoriasis. Dermatol. Clin. 2015, 33, 1-11. [CrossRef] [PubMed]

15. Swindell, W.R.; Stuart, P.E.; Sarkar, M.K.; Voorhees, J.J.; Elder, J.T.; Johnston, A.; Gudjonsson, J.E. Cellular dissection of psoriasis for transcriptome analyses and the post-GWAS era. BMC Med. Genom. 2014, 7, 27. [CrossRef] [PubMed]

16. Sun, L.D.; Cheng, H.; Wang, Z.X.; Zhang, A.P.; Wang, P.G.; Xu, J.H.; Zhu, Q.X.; Zhou, H.S.; Ellinghaus, E.; Zhang, F.R.; et al. Association analyses identify six new psoriasis susceptibility loci in the Chinese population. Nat. Genet. 2010, 42, 1005-1009. [CrossRef] [PubMed]

17. Tas, F.; Atsu, N. Exacerbation of psoriasis induced by interferon-alpha treatment for melanoma. Cutan. Ocul. Toxicol. 2016, 35, 83-84. [CrossRef] [PubMed]

18. Wang, Y.; Weng, H.; Song, J.F.; Deng, Y.H.; Li, S.; Liu, H.B. Activation of the HMGB1-TLR4-NF-kB pathway may occur in patients with atopic eczema. Mol. Med. Rep. 2017, 16, 2714-2720. [CrossRef] [PubMed]

19. Lam, C.T.; Sarah, L.S.; Knight, J.; Ellinghaus, E.; Philip, E.S.; Francesca, C.; Ding, J.; Li, Y.; Tejasvi, T.; Gudjonsson, J.E.; et al. Identification of fifteen new psoriasis susceptibility loci highlights the role of innate immunity. Nat. Genet. 2012, 44, 1341-1348.

20. Sugiura, K. The genetic background of generalized pustular psoriasis: IL36RN mutations and CARD14 gain-of-function variants. J. Dermatol. Sci. 2014, 74, 187-192. [CrossRef] [PubMed]

21. Jordan, C.T.; Cao, L.; Roberson, E.D.; Pierson, K.C.; Yang, C.F.; Joyce, C.E.; Ryan, C.; Duan, S.; Helms, C.A.; Liu, Y.; et al. PSORS2 is due to mutations in CARD14. Am. J. Hum. Genet. 2012, 90, 784-795. [CrossRef] [PubMed]

22. Blumberg, H.; Dinh, H.; Trueblood, E.S.; Pretorius, J.; Kugler, D.; Weng, N.; Kanaly, S.T.; Towne, J.E.; Willis, C.R.; Kuechle, M.K.; et al. Opposing activities of two novel members of the IL-1 ligand family regulate skin inflammation. J. Exp. Med. 2007, 204, 2603-2614. [CrossRef] [PubMed]

23. Onoufriadis, A.; Simpson, M.A.; Pink, A.E.; Di Meglio, P.; Smith, C.H.; Pullabhatla, V.; Knight, J.; Spain, S.L.; Nestle, F.O.; Burden, A.D.; et al. Mutations in IL36RN/IL1F5 are associated with the severe episodic inflammatory skin disease known as generalized pustular psoriasis. Am. J. Hum. Genet. 2011, 89, $432-437$. [CrossRef] [PubMed]

24. Bijlmakers, M.J.; Kanneganti, S.K.; Barker, J.N.; Trembath, R.C.; Capon, F. Functional analysis of the RNF114 psoriasis susceptibility gene implicates innate immune responses to double-stranded RNA in disease pathogenesis. Hum. Mol. Genet. 2011, 20, 3129-3137. [CrossRef] [PubMed]

25. Stawczyk-Macieja, M.; Szczerkowska-Dobosz, A.; Rębała, K.; Purzycka-Bohdan, D. Genetic background of skin barrier dysfunction in the pathogenesis of psoriasis vulgaris. Postepy Dermatol. Alergol. 2015, 32, 123-126. [CrossRef] [PubMed]

26. Zhang, X.J.; Huang, W.; Yang, S.; Sun, L.D.; Zhang, F.Y.; Zhu, Q.X.; Zhang, F.R.; Zhang, C.; Du, W.H.; $\mathrm{Pu}$, X.M.; et al. Psoriasis genome-wide association study identifies susceptibility variants within LCE gene cluster at 1q21. Nat. Genet. 2009, 41, 205-210. [CrossRef] [PubMed]

27. Relle, M.; Schwarting, A. Role of MHC-linked susceptibility genes in the pathogenesis of human and murine lupus. Clin. Dev. Immunol. 2012, 2012, 584374. [CrossRef] [PubMed]

28. Prinz, J.C. Melanocytes: Target Cells of an HLA-C*06:02-Restricted Autoimmune Response in Psoriasis. J. Investig. Dermatol. 2017, 137, 2053-2058. [CrossRef] [PubMed]

29. Arakawa, A.; Siewert, K.; Stöhr, J.; Besgen, P.; Kim, S.M.; Rühl, G.; Nickel, J.; Vollmer, S.; Thomas, P.; Krebs, S.; et al. Melanocyte antigen triggers autoimmunity in human psoriasis. J. Exp. Med. 2015, 212, 2203-2212. [CrossRef] [PubMed]

30. Amy, S.; Francesca, C.; Chris, C.A.S.; Knight, J.; Michael, E.W.; Michael, H.A.; Barton, A.; Band, G.; Bellenguez, C.; Bergboer, J.G.; et al. Genome-wide association study identifies new psoriasis susceptibility loci and an interaction between HLA-C and ERAP1. Nat. Genet. 2010, 42, 985-990. 
31. Mease, P.J.; Genovese, M.C.; Greenwald, M.W.; Ritchlin, C.T.; Beaulieu, A.D.; Deodhar, A.; Newmark, R.; Feng, J.; Erondu, N.; Nirula, A. Brodalumab, an anti-IL17RA monoclonal antibody, in psoriatic arthritis. N. Engl. J. Med. 2014, 370, 2295-2306. [CrossRef] [PubMed]

32. Elyoussfi, S.; Thomas, B.J.; Ciurtin, C. Tailored treatment options for patients with psoriatic arthritis and psoriasis: Review of established and new biologic and small molecule therapies. Rheumatol. Int. 2016, 36, 603-612. [CrossRef] [PubMed]

33. Chang, M.; Li, Y.; Yan, C.; Callis-Duffin, K.P.; Matsunami, N.; Garcia, V.E.; Cargill, M.; Civello, D.; Bui, N.; Catanese, J.J. Variants in the $5 \mathrm{q} 31$ cytokine gene cluster are associated with psoriasis. Genes Immun. 2008, 9, 176-181. [CrossRef] [PubMed]

34. Zhang, P.; Chen, H.X.; Duan, Y.Q.; Wang, W.Z.; Zhang, T.Z.; Li, J.W.; Tu, Y.T. Analysis of Th1/Th2 response pattern for erythrodermic psoriasis. J. Huazhong Univ. Sci. Technol. Med. Sci. 2014, 34, 596-601. [CrossRef] [PubMed]

35. Jordan, C.T.; Cao, L.; Roberson, E.D.; Duan, S.; Helms, C.A.; Nair, R.P.; Duffin, K.C.; Stuart, P.E.; Goldgar, D.; Hayashi, G.; et al. Rare and common variants in CARD14, encoding an epidermal regulator of NF- $\mathrm{kB}$, in psoriasis. Am. J. Hum. Genet. 2012, 90, 796-808. [CrossRef] [PubMed]

36. Flisiak, I.; Szterling-Jaworowska, M.; Baran, A.; Rogalska-Taranta, M. Effect of psoriasis activity on epidermal growth factor (EGF) and the concentration of soluble EGF receptor in serum and plaque scales. Clin. Exp. Dermatol. 2014, 39, 461-467. [CrossRef] [PubMed]

37. Puig, L.; Julià, A.; Marsal, S. The pathogenesis and genetics of psoriasis. Actas Dermosifiliogr. 2014, 105, 535-545. [CrossRef] [PubMed]

38. Martin, D.A.; Towne, J.E.; Kricorian, G.; Klekotka, P.; Gudjonsson, J.E.; Krueger, J.G.; Russell, C.B. The emerging role of IL-17 in the pathogenesis of psoriasis: Preclinical and clinical findings. J. Investig. Dermatol. 2013, 133, 17-26. [CrossRef] [PubMed]

39. Guenova, E.; Skabytska, Y.; Hoetzenecker, W.; Weindl, G.; Sauer, K.; Tham, M. IL-4 abrogates T(H)17 cell-mediated inflammation by selective silencing of IL-23 in antigen-presenting cells. Proc. Natl. Acad. Sci. USA 2015, 112, 2163-2168. [CrossRef] [PubMed]

40. Liu, J.L.; Zhang, S.Q.; Zeng, H.M. ApaI, BsmI, FokI and TaqI polymorphisms in the vitamin D receptor (VDR) gene and the risk of psoriasis: A meta-analysis. J. Eur. Acad. Dermatol. Venereol. 2013, 27, 739-746. [CrossRef] [PubMed]

41. Qi, M.; Huang, X.; Zhou, L.; Zhang, J. Four polymorphisms of VEGF $(+405 \mathrm{C}>\mathrm{G},-460 \mathrm{~T}>\mathrm{C},-2578 \mathrm{C}>\mathrm{A}$, and $-1154 \mathrm{G}>\mathrm{A}$ ) in susceptibility to psoriasis: A meta-analysis. DNA Cell Biol. 2014, 33, 234-244. [CrossRef] [PubMed]

42. Papoutsaki, M.; Costanzo, A. Treatment of psoriasis and psoriatic arthritis. BioDrugs 2013, 27, 3-12. [CrossRef] [PubMed]

43. Ovejero-Benito, M.C.; Muñoz-Aceituno, E.; Reolid, A.; Saiz-Rodríguez, M.; Abad-Santos, F.; Daudén, E. Pharmacogenetics and Pharmacogenomics in Moderate-to-Severe Psoriasis. Am. J. Clin. Dermatol. 2017, 1-14. [CrossRef] [PubMed]

44. Wang, Z.Y.; Fu, L.Y.; Zhang, H.Y. Can medical genetics and evolutionary biology inspire drug target identification? Trends Mol. Med. 2012, 18, 69-71. [CrossRef] [PubMed]

45. Andrés, R.M.; Montesinos, M.C.; Navalón, P.; Payá, M.; Terencio, M.C. NF-кB and STAT3 inhibition as a therapeutic strategy in psoriasis: In vitro and in vivo effects of BTH. J. Investig. Dermatol. 2013, 133, 2362-2371. [CrossRef] [PubMed]

46. Zheng, X.F.; Sun, Y.D.; Liu, X.Y. Correlation of expression of STAT3, VEGF and differentiation of Th17 cells in psoriasis vulgaris of guinea pig. Asian Pac. J. Trop. Med. 2014, 7, 313-316. [CrossRef]

47. Grine, L.; Dejager, L.; Libert, C.; Vandenbroucke, R.E. An inflammatory triangle in psoriasis: TNF, type I IFNs and IL-17. Cytokine Growth Factor Rev. 2015, 26, 25-33. [CrossRef] [PubMed]

48. Richetta, A.G.; Silvestri, V.; Giancristoforo, S.; Rizzolo, P.; D’Epiro, S.; Graziano, V.; Mattozzi, C.; Navazio, A.S.; Campoli, M.; D'Amico, C.; et al. A-1012G promoter polymorphism of vitamin D receptor gene is associated with psoriasis risk and lower allele-specific expression. DNA Cell Biol. 2014, 33, 102-109. [CrossRef] [PubMed]

49. Coto-Segura, P.; Coto, E.; Mas-Vidal, A.; Morales, B.; Alvarez, V.; Díaz, M. Influence of endothelial nitric oxide synthase polymorphisms in psoriasis risk. Arch. Dermatol. Res. 2011, 303, 445-449. [CrossRef] [PubMed]

50. Ruuls, S.R.; Lammerts van Bueren, J.J.; van de Winkel, J.G.; Parren, P.W. Novel human antibody therapeutics: The age of the Umabs. Biotechnol. J. 2008, 3, 1157-1171. [CrossRef] [PubMed] 
51. Okamoto, K.; Maeda, H.; Shiga, T.; Shiga, M.; Dabanaka, K.; Hanazaki, K.; Kobayashi, M. Cetuximab and panitumumab in a patient with colon cancer and concomitant chronic skin disease: A potential beneficial effect on psoriasis vulgaris. World J. Gastroenterol. 2015, 21, 3746-3749. [CrossRef] [PubMed]

52. Nishizawa, A.; Satoh, T.; Yokozeki, H. Erythrodermic psoriasis improved by panitumumab, but not bevacizumab. Acta Derm.-Venereol. 2012, 92, 360-361. [CrossRef] [PubMed]

53. Reichert, J.M. Antibodies to watch in 2014. MAbs 2014, 6, 5-14. [CrossRef] [PubMed]

54. Frenzel, A.; Schirrmann, T.; Hust, M. Phage display-derived human antibodies in clinical development and therapy. MAbs 2016, 8, 1177-1194. [CrossRef] [PubMed]

55. Mas-Vidal, A.; Coto-Segura, P.; Galache-Osuna, C.; Santos-Juanes, J. Psoriasis induced by cetuximab: A paradoxical adverse effect. Australas. J. Dermatol. 2011, 52, 56-58. [CrossRef] [PubMed]

56. Neyns, B.; Meert, V.; Vandenbroucke, F. Cetuximab treatment in a patient with metastatic colorectal cancer and psoriasis. Curr. Oncol. 2008, 15, 196-197. [CrossRef] [PubMed]

57. Moghddam, S.R.; Ahad, A.; Aqil, M.; Imam, S.S.; Sultana, Y. Formulation and optimization of niosomes for topical diacerein delivery using 3-factor, 3-level Box-Behnken design for the management of psoriasis. Mater. Sci. Eng. C Mater. Biol. Appl. 2016, 69, 789-797. [CrossRef] [PubMed]

58. Kim, C.H.; Kim, J.Y.; Lee, A.Y. Therapeutic and immunomodulatory effects of glucosamine in combination with low-dose cyclosporine a in a murine model of imiquimod-induced psoriasis. Eur. J. Pharmacol. 2015, 756, 43-51. [CrossRef] [PubMed]

59. Hoffmann, M.; Kasserra, C.; Reyes, J.; Schafer, P.; Kosek, J.; Capone, L.; Parton, A.; Kim-Kang, H.; Surapaneni, S.; Kumar, G. Absorption, metabolism and excretion of $\left[{ }^{14} \mathrm{C}\right]$ pomalidomide in humans following oral administration. Cancer Chemother. Pharmacol. 2013, 71, 489-501. [CrossRef] [PubMed]

60. Garber, C.; Plotnikova, N.; Au, S.C.; Sorensen, E.P.; Gottlieb, A. Biologic and conventional systemic therapies show similar safety and efficacy in elderly and adult patients with moderate to severe psoriasis. J. Drugs Dermatol. 2015, 14, 846-852. [PubMed]

61. Reich, K.; Ortonne, J.P.; Gottlieb, A.B.; Terpstra, I.J.; Coteur, G.; Tasset, C.; Mease, P. Successful treatment of moderate to severe plaque psoriasis with the PEGylated Fab' certolizumab pegol: Results of a phase II randomized, placebo-controlled trial with a re-treatment extension. Br. J. Dermatol. 2012, 167, 180-190. [CrossRef] [PubMed]

62. Brezinski, E.A.; Armstrong, A.W. An evidence-based review of the mechanism of action, efficacy, and safety of biologic therapies in the treatment of psoriasis and psoriatic arthritis. Curr. Med. Chem. 2015, 22, 1930-1942. [CrossRef] [PubMed]

63. Komrokji, R.S.; Kulasekararaj, A.; Al Ali, N.H.; Kordasti, S.; Bart-Smith, E.; Craig, B.M. Autoimmune diseases and myelodysplastic syndromes. Am. J. Hematol. 2016, 91, E280-E283. [CrossRef] [PubMed]

64. Deng, A.; Harvey, V.; Sina, B.; Strobel, D.; Badros, A.; Junkins-Hopkins, J.M.; Samuels, A.; Oghilikhan, M.; Gaspari, A. Interstitial granulomatous dermatitis associated with the use of tumor necrosis factor alpha inhibitors. Arch. Dermatol. 2006, 142, 198-202. [CrossRef] [PubMed]

65. Datta-Mitra, A.; Riar, N.K.; Raychaudhuri, S.P. Remission of psoriasis and psoriatic arthritis during bevacizumab therapy for renal cell cancer. Indian J. Dermatol. 2014, 59, 632. [PubMed]

66. Popa, A.M.; Valla, K.; Radhakrishnan, L.; Cuellar, S.; Villano, J.L. Bevacizumab-induced oral mucositis in background of cutaneous plaque-type psoriasis. Ann. Pharmacother. 2012, 46, e32. [CrossRef] [PubMed]

67. Udkoff, J.; Cohen, P.R. Severe Infliximab-induced alopecia and scalp psoriasis in a woman with crohn's disease: Dramatic improvement after drug discontinuation and treatment with adjuvant systemic and topical therapies. Dermatol. Ther. 2016, 6, 689-695. [CrossRef] [PubMed]

68. Min, L.; Kensuke, M.; Takashi, H.; Naoyuki, H. Epidermolysis bullosa acquisita in a patient with psoriasis vulgaris. Eur. J. Dermatol. 2015, 25, 499-500. [PubMed]

69. Janier, M. What's new in clinical dermatology? Ann. Dermatol. Venereol. 2013, 140, S237-S253. [CrossRef]

(C) 2017 by the authors. Licensee MDPI, Basel, Switzerland. This article is an open access article distributed under the terms and conditions of the Creative Commons Attribution (CC BY) license (http:/ / creativecommons.org/licenses/by/4.0/). 